\title{
The composition of mixed-species foraging flocks of birds in Kruger National Park, South Africa
}

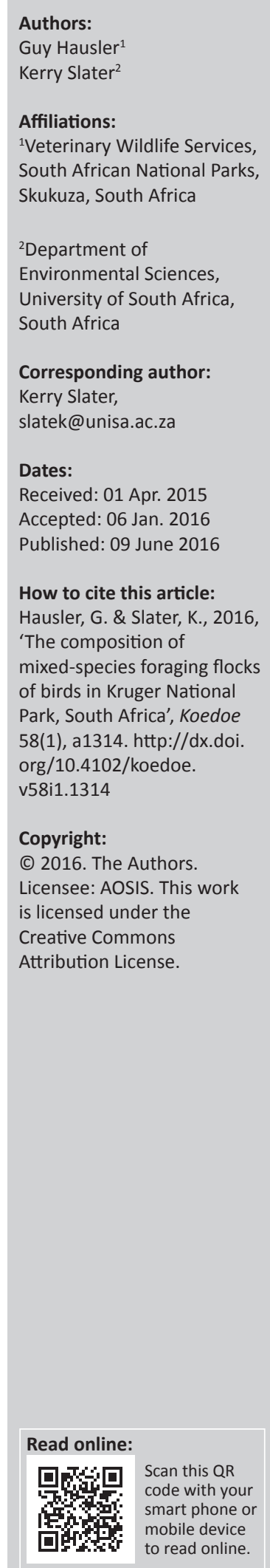

Mixed-species foraging flocks (MSFFs) of birds can be defined as aggregations of more than two species that actively initiate and continue their association while foraging, without being drawn to a single resource. MSFFs have been well documented for terrestrial habitats globally, but rarely in southern Africa. This study describes the composition of MSFFs in two habitat types (Acacia and Combretum) within the southern Kruger National Park, South Africa during the late dry season. Thirty-one MSFFs were recorded in each of the two habitat types, with 1251 individuals of 74 different species being observed. We found that compared to Combretum, (mean: $10.7 \pm 5.2$ s.d.) Acacia had significantly more individuals per MSFFs (mean: $21.5 \pm 12.6$ s.d.) and more species per MSFF (Acacia mean: $8.7 \pm 3.5$ s.d.; Combretum mean: $5.9 \pm 1.7$ s.d.). The mean number of individuals per species per 31 MSFFs was 9.3 ( \pm 4.5 s.d.) and 7.6 ( \pm 5.6 s.d.) in the Acacia and Combretum habitat types respectively. The most frequently occurring species in both habitat types was the Fork-tailed Drongo (Dicrurus adsimilis). There was a significant association between certain species pairs in both habitats. Future studies in this area could be done to investigate the reasons behind the differences in MSFF sizes and species numbers between habitats. The season during which this study was performed excluded all summer migrants and a similar investigation in the wet season may reveal a different MSFF composition.

Conservation implications: Understanding the dynamics and compositions of MSFFs, could form a valuable component of avian biodiversity monitoring both in and outside of protected areas. Within a given area, changes in the composition and behaviour of MSFFs over time could potentially be used as early indicator of threats to biodiversity.

\section{Introduction}

Mixed-species foraging flocks (MSFFs) of birds can be defined as aggregations of more than two species that actively initiate and continue their association (Harrison \& Whitehouse 2011) while foraging in an area or habitat (Greig-Smith 1978). Despite the global prevalence of MSFFs among terrestrial bird communities (Harrison \& Whitehouse 2011; Morse 1970) MSFFs have rarely been characterised in southern Africa. The presence and role of each species in a flock reflects its ecological niche as well as the various factors leading to flock formation (Morse 1970).

In temperate areas, MSSFs tend to form more readily in non-breeding seasons (Morse 1970) and differ from other aggregations of birds in their cohesion, rather than being a gathering of different species drawn to a particular resource (such as a fruiting tree); these flocks remain together as they progress through the habitat (Goodale \& Beauchamp 2010). Only those individuals that lead the flock or make a concerted effort to follow and remain in the flock should be considered as MSFF members (GreigSmith 1978). MSFFs are typically led by a particular species, a role typically fulfilled by a so-called 'nucleus species'. A nucleus species is usually a species with high flocking propensity, encountered in a high percentage of MSFFs, often occurs in intra-specific flocks, and usually displays conspicuous behaviour such as vocalising or making conspicuous movements (Hutto 1994). The individuals of a nucleus species are wholly or partially responsible for the formation and continued cohesion of the MSFF (Goodale \& Beauchamp 2010; Greig-Smith 1978; Morse 1970) with other species in the MSFF organising their various activities around the nucleus species. Although various feeding guilds are present, MSFFs are usually dominated by insectivorous species (Croxall 1976; Greig-Smth 1978).

In some habitats multiple types of MSFFs may be distinguished, based on differences in foraging height (Zou et al. 2011) or the presence of particular species or guilds (King \& Rappole 2001). Although some authors have suggested that the regular occurrence of a given species in MSFFs is directly related to the abundance of the species (Morse 1978; Zou et al. 2011), this is not always the case in savanna ecosystems (Greig-Smith 1978). Furthermore, some species may be recorded in MSFFs only when the flock happens to move through the territory of that species (Greig-Smith 1978). The mean number of species per MSFF ranges from 3.8 in forested areas in 
China (Zou et al. 2011) to 7.7 and 9.9 in the former eastern provinces and Barotse of Northern Rhodesia respectively (Winterbottom 1943). Furthermore, although differences between MSFFs observed in different vegetation types within one geographical area may be minimal (Croxall 1976; Winterbottom 1943), MSFFs in adjacent Acacia and mixed woodland habitats in northern South Africa do show significant differences in composition and mean number of species (Thomson \& Ferguson 2007).

To date, MSFFs occurring in any of the various savanna habitats of the Kruger National Park (KNP), South Africa have not been investigated despite the major role that birds play in savanna ecosystems and the maintenance of savanna heterogeneity (Kemp et al. 2003). The main aim of this study was to investigate the composition of MSFFs in a southern section of KNP.

\section{Research method and design \\ Study area}

The study area comprises the Sabie/Crocodile Thorn Thickets landscape type (Gertenbach 1983) located in the southern KNP. This entire landscape is underlain by granites (Venter, Scholes \& Eckhardt 2003) with crests and mid-slopes supporting broad-leaved Combretum bushveld, whereas foot-slopes are dominated by fine-leaved tree species (particularly Acacia spp.). The foot-slopes display two principle forms of woodland: one has a dense, tangled understory, while the other, found in brackish (sodic) areas, has minimal understory vegetation and large bare patches of soil, typically beneath Acacia grandicornuta (horned-thorn) trees (Gertenbach 1983). The sites surveyed for MSFFs in this study fall within this landscape type and lie in the area bound by the S65 gravel road in the west and Nkuhlu picnic spot in the east (Figure 1). For the purpose of this study the following habitats were investigated: Combretumdominated bushveld on crests and Acacia-dominated woodland in the lowlands, hereafter referred to as Combretum and Acacia respectively. The study area falls within a summer rainfall region with an average of between $511 \mathrm{~mm}$ and $566 \mathrm{~mm}$ of rain annually. The average maximum and minimum daily temperatures are $32.6{ }^{\circ} \mathrm{C}$ and $20.6{ }^{\circ} \mathrm{C}$ in summer (November - February), dropping to $25.9{ }^{\circ} \mathrm{C}$ and $5.6^{\circ} \mathrm{C}$ in winter (May - August) respectively (Venter et al. 2003).

\section{Procedure}

Surveys were conducted on 16 days during the late dry season (July - early September 2013) and restricted to 06:00 - 10:00 and 16:00 - 17:00 each sampling day to coincide with the greatest levels of bird activity (pers. obs.). Data were collected by walking or driving through suitable areas of the landscape until a MSFF was encountered. The MSFF was then observed from a fairly fixed point for as long as the MSFF remained cohesive and/or as long as new species continued to join the MSFF (typically $>12 \mathrm{~min}$ ). Recording of data stopped when the MSFF dispersed or if visual contact of the MSFF was lost.

To ensure that no MSFF was sampled more than once we tried to avoid sampling the same area multiple times. However, some areas were sampled on more than one occasion, but this was only done after an interval of more than 10 days to minimise repetitive sampling of particular MSFFs. Unfortunately wider sampling within the study area was not possible because of restrictions on human movement enforced by park management as a result of anti-poaching operations at the time of the study. Both Acacia and Combretum were surveyed on each sampling day to eliminate as far as possible, effects of weather conditions. The slope position
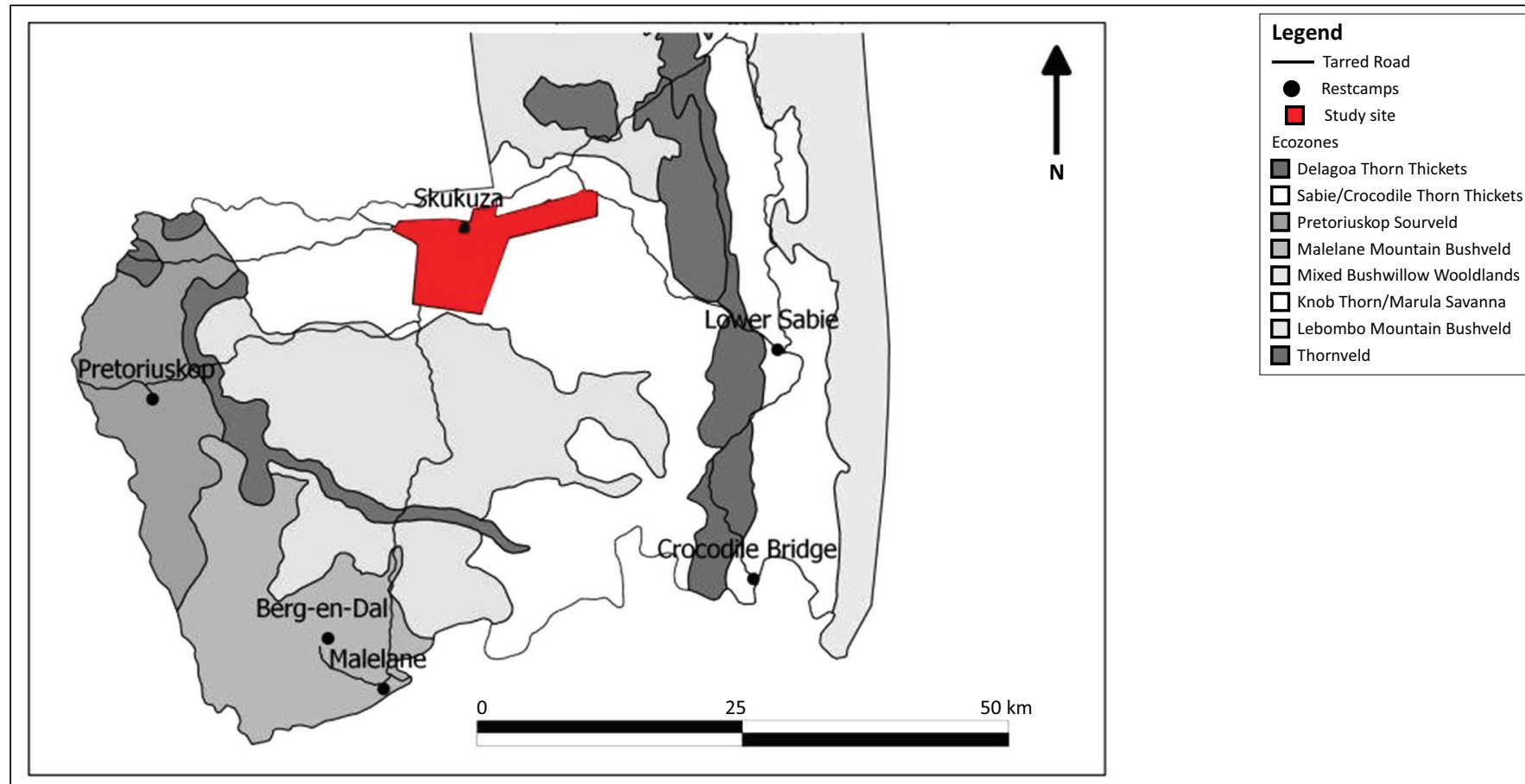

Source: Adapted from Venter, F.J., 1990, 'A classification of land for management planning in the Kruger National Park', PhD thesis, University of South Africa, Pretoria FIGURE 1: Location of study area, southern Kruger National Park, showing landscapes. 
(i.e. crest, foot-slope, etc.), dominant woody vegetation, and a KNP vegetation map (derived from Venter 1990) were used for classifying sites. Site specific information recorded for each MSFF included vegetation type, GPS position, date, time, cloud cover, and any interesting MSFF behaviour. Observations were made with the aid of a pair of Zeiss 10x40 binoculars and a hand-held electronic range finder was used for the estimation of 20-m distances.

The species within each MSFF were identified as per Hockey, Dean and Ryan (2005) and recorded along with the numbers of individuals of each species. Species foraging in all vegetation strata as well as on the ground were recorded as long as they showed clear tendencies to join and follow the MSFF. Species using a sit-and-wait hunting technique, which made no effort to follow the MSFF as it traversed their position, were ignored, as were aerial species such as swifts (Apodidae). Only bird species observed within a 20-meter radius of the core of the MSFF's activities (such as a particular tree) were recorded, as the dense nature of some of the areas surveyed prevented observations over a wider area.

We calculated the number of individuals per species across all MSFF's and the frequency of occurrence of each species in MSFFs. We then calculated the following: the mean number of individuals per MSFF, the number of species per MSFF, and the number of individuals per species per MSFF. A Wilcoxon rank sum test was used to investigate whether there were any significant differences in the number of individuals and species per MSFF between the two habitat types. Associations between species in MSFFs were examined by scoring each species as either present (1) or absent (0) in each MSFF. This presence-absence data was then analysed using a Pearson's correlation to give a measure of association between two species.

\section{Results}

During the study period, 62 MSFFs were encountered, equally divided between the two habitat types (i.e. 31 MSFFs in Acacia and 31 MSFFs in Combretum). In total 1251 individuals of 74 different species were observed in these MSFFs. Of these 74 species, 29 species in Acacia and 24 species in Combretum were regarded as regular flocking species (species that occurred in > 10\% of flocks; King \& Rappole 2001). Only these species were used for further analysis (Table 1$)$. Of the $32(43 \%)$ species that were regarded as regular flocking species, 21 species $(28 \%)$ were recorded in both the Acacia and the Combretum, 8 (11\%) in the Acacia only, and 3 (4\%) in the Combretum only.

Across flocks the mean number of individuals per species was 9.3 ( \pm 4.5 s.d.) and 7.6 ( \pm 5.6 s.d.) in the Acacia and Combretum habitat types respectively. Results from the Wilcoxon rank sum test indicated that MSFFs in Acacia had significantly $(P<0.0001$, $n=31, \mathrm{Z}=4.2$ ) more individuals per MSFFs (mean: $21.5 \pm$ 12.6 s.d.) than those in Combretum (mean: $10.7 \pm 5.2$ s.d.). A significant difference $(\mathrm{T}=3.91 ; P=0.0003)$ in the number of species per MSFF between the Acacia and Combretum was also found, with the Acacia having a mean number of species per MSFF of 8.7 ( \pm 3.5 s.d.) and the Combretum 5.9 ( \pm 1.7 s.d.).
The frequency of occurrence of a recorded species in the MSFFs often varied according to habitat type. The three most frequently occurring species in Acacia MSFFs were Forktailed Drongo (Dicrurus adsimilis), Southern Black Tit (Melaniparus viger), and Chinspot Batis (Batis molitor); whereas in Combretum they were Fork-tailed Drongo, Rattling Cisticola (Cisticola chiniana), and Chinspot Batis (Table 1).

There were 26 significant correlations among species pairs in the Acacia habitat of which 20 were positive (Table 2). Of these, the strongest associations are between Southern Yellow-billed hornbills (Tockus leucomelas), Fiscal Flycatchers (Melaenornis silens), and Southern Red-billed Hornbills (Tockus rufirostris); Black-backed Puffbacks (Dryoscopus cubla) and Tawny-flanked Prinias (Prinia subflava); Southern Greyheaded Sparrows (Passer diffuses) with Fiscal Flycatchers; and Southern Masked Weavers (Ploceus velatus), with Arrowmarked Babblers (Turdoides jardineii).

In the Combretum habitat there were nine significant correlations among species pairs of which five were positive (Table 3). The following positive correlations were found in the Combretum habitat: Long-billed Crombecs (Sylvietta rufescens) with Rattling Cisticola, Emerald-spotted Wood Doves (Turtur chalcospilos) and Blue Waxbills (Uraeginthus angolensis) with Arrow-marked Babblers, Southern Grey-headed Sparrows with Yellow-fronted Canaries (Crithagra mozambica), Green Wood Hoopoes (Phoeniculus purpureus) with Black-backed Puffbacks. Negative correlations in the Combretum habitat included those between Chinspot Batis' and Arrow-marked Babblers; Red-billed Firefinches (Lagonosticta senegala) with Arrow-marked Babblers; Greater Blue-eared Starlings (Lamprotornis chalybaeus) with Fork-tailed drongos; and Cardinal Woodpeckers (Dendropicos fuscescens) with Rattling Cisticolas.

\section{Discussion}

The MSFFs observed during this study had mean MSFF sizes similar to the mean MSFF size (16.9-19.3) recorded in tropical forests in Myanmar, Southeast Asia (Croxall 1976; King \& Rappole 2001) and west African savannas (23.2) (Greig-Smith 1978). The mean number of species per MSFF was comparable to MSFFs studied in other African savannas (Winterbottom 1943). Acacia supported larger flocks and a greater number of species per flock when compared to the Combretum. MSFFs in adjacent Acacia and mixed woodland habitats in northern South Africa also showed significant differences in composition and mean number of species (Thomson \& Ferguson 2007). Acacia also exhibited a higher mean number of species per MSFF, possibly because of having greater structural complexity than Combretum. Species diversity typically increases with structural complexity of habitat (Skwono \& Bond 2003).

Testing this hypothesis is however beyond the scope of this study, and reasons for these differences in MSFF sizes and species numbers between habitats would make for interesting future study. Having said this, the majority of species recorded in MSFFs in this study were recorded in both habitat 
types surveyed. In some cases, inconspicuous MSFF participants such as Stierling's Wren-Warbler (Calamonastes stierlingi) may have been under-recorded because of the dense nature of the habitats in which they occurred. This would lead to underrepresentation of these species in the results. Although such species could have been actively revealed by flushing them, this would have led to MSFF dispersal and was thus deemed unsuitable.

In both vegetation types, Fork-tailed drongos occurred in $71 \%$ of MSFFs, a similar finding to that of many other studies where drongos were recorded as common MSFF participants

TABLE 1: Bird species observed in more than $10 \%$ of mixed-species foraging flocks in Acacia ( $n=31$ flocks) and Combretum ( $n=31$ flocks) habitat types in Kruger National Park, South Africa.

\begin{tabular}{|c|c|c|c|c|c|c|c|}
\hline \multirow[t]{2}{*}{ Habitat type } & \multirow[t]{2}{*}{ Common name } & \multirow[t]{2}{*}{ Scientific name } & \multirow{2}{*}{$\begin{array}{l}\text { Occurrence of } \\
\text { species }\end{array}$} & \multirow{2}{*}{$\begin{array}{l}\text { Frequency of } \\
\text { occurrence }\end{array}$} & \multicolumn{2}{|c|}{ Individuals } & \multirow[t]{2}{*}{ Code } \\
\hline & & & & & mean \pm s.d. & Total & \\
\hline \multirow[t]{29}{*}{ Acacia } & Chinspot Batis & Batis molitor & 22 & 0.71 & $2.05 \pm 0.58$ & 45 & CSB \\
\hline & Fork-tailed Drongo & Dicrurus adsimilis & 22 & 0.71 & $1.45 \pm 0.51$ & 32 & FTD \\
\hline & Southern Black Tit & Parus niger & 16 & 0.52 & $2.38 \pm 1.63$ & 38 & SBT \\
\hline & White-browed Scrub Robin & Cercotrichas leucophrys & 13 & 0.42 & $1.08 \pm 0.28$ & 14 & WBSR \\
\hline & Emerald-spotted Wood Dove & Turtur chalcospilos & 12 & 0.39 & $1.42 \pm 0.79$ & 17 & ESWD \\
\hline & Yellow-breasted Apalis & Apalis flavida & 11 & 0.35 & $2.00 \pm 0.45$ & 22 & YBA \\
\hline & Ring-necked Dove & Streptopelia capicola & 11 & 0.35 & $3.36 \pm 3.17$ & 37 & RND \\
\hline & Blue Waxbill & Uraeginthus angolensis & 11 & 0.35 & $4.63 \pm 3.78$ & 51 & BW \\
\hline & Cardinal Woodpecker & Dendropicos fuscescens & 11 & 0.35 & $1.36 \pm 0.50$ & 15 & $\mathrm{CW}$ \\
\hline & Long-billed Crombec & Sylvietta rufescens & 10 & 0.32 & $2.10 \pm 0.99$ & 21 & LBC \\
\hline & Southern Grey-headed Sparrow & Passer diffusus & 10 & 0.32 & $9.60 \pm 14.88$ & 96 & SGHS \\
\hline & Yellow-fronted Canary & Crithagra mozambica & 9 & 0.29 & $7.11 \pm 6.82$ & 64 & YFC \\
\hline & Rattling Cisticola & Cisticola chiniana & 9 & 0.29 & $2.44 \pm 1.13$ & 22 & $\mathrm{RC}$ \\
\hline & Black-backed Puffback & Dryoscopus cubla & 9 & 0.29 & $1.22 \pm 0.44$ & 11 & BBP \\
\hline & Brubru & Nilaus afer & 8 & 0.26 & $1.25 \pm 0.46$ & 10 & BB \\
\hline & Orange-breasted Bushshrike & $\begin{array}{l}\text { Chlorophoneus } \\
\text { sulfureopectus }\end{array}$ & 8 & 0.26 & $1.00 \pm 0.00$ & 8 & OBBS \\
\hline & Tawny-flanked Prinia & Prinia subflava & 8 & 0.26 & $2.63 \pm 1.60$ & 21 & TFP \\
\hline & White-bellied Sunbird & Cinnyris talatala & 8 & 0.26 & $1.63 \pm 0.52$ & 13 & WBS \\
\hline & Dark-capped Bulbul & Pycnonotus tricolor & 7 & 0.23 & $1.71 \pm 0.49$ & 12 & DCB \\
\hline & Brown-crowned Tchagra & Tchagra australis & 7 & 0.23 & $1.00 \pm 0.00$ & 7 & $\mathrm{BCT}$ \\
\hline & Fiscal Flycatcher & Melaenornis silens & 6 & 0.19 & $1.67 \pm 0.52$ & 10 & $\mathrm{FF}$ \\
\hline & Southern Red-billed Hornbill & Tockus rufirostris & 6 & 0.19 & $3.17 \pm 2.14$ & 19 & SRH \\
\hline & Brown-hooded Kingfisher & Halcyon albiventris & 6 & 0.19 & $1.00 \pm 0.00$ & 6 & BHK \\
\hline & Southern Masked Weaver & Ploceus velatus & 6 & 0.19 & $1.33 \pm 0.52$ & 8 & SMW \\
\hline & Arrow-marked Babbler & Turdoides jardineii & 5 & 0.16 & $5.60 \pm 0.55$ & 28 & AMB \\
\hline & Red-billed Firefinch & Lagonosticta senegala & 5 & 0.16 & $3.00 \pm 3.39$ & 15 & RBF \\
\hline & Southern Yellow-billed Hornbill & Tockus leucomelas & 5 & 0.16 & $1.8 \pm 0.84$ & 9 & SYBH \\
\hline & Golden-breasted Bunting & Emberiza flaviventris & 4 & 0.13 & $2.25 \pm 1.89$ & 9 & GBB \\
\hline & Burchell's Starling & Lamprotornis australis & 4 & 0.13 & $2.00 \pm 0.00$ & 8 & BS \\
\hline \multirow[t]{23}{*}{ Combretum } & Fork-tailed Drongo & Dicrurus adsimilis & 23 & 0.74 & $1.57 \pm 0.59$ & 36 & FTD \\
\hline & Rattling Cisticola & Cisticola chiniana & 19 & 0.61 & $2.53 \pm 1.68$ & 48 & $\mathrm{RC}$ \\
\hline & Chinspot Batis & Batis molitor & 18 & 0.58 & $1.89 \pm 0.58$ & 34 & $\mathrm{CB}$ \\
\hline & Southern Black Tit & Parus niger & 15 & 0.48 & $1.60 \pm 0.63$ & 24 & SBT \\
\hline & Long-billed Crombec & Sylvietta rufescens & 13 & 0.42 & $2.15 \pm 1.14$ & 28 & LBC \\
\hline & Brown-crowned Tchagra & Tchagra australis & 8 & 0.26 & $1.13 \pm 0.35$ & 9 & $\mathrm{BCT}$ \\
\hline & Yellow-breasted Apalis & Apalis flavida & 6 & 0.19 & $1.67 \pm 0.51$ & 10 & YBA \\
\hline & Golden-breasted Bunting & Emberiza flaviventris & 6 & 0.19 & $1.33 \pm 0.52$ & 8 & GBB \\
\hline & Black-backed Puffback & Dryoscopus cubla & 6 & 0.19 & $1.17 \pm 0.41$ & 7 & BBP \\
\hline & Black-crowned Tchagra & Tchagra senegalus & 6 & 0.19 & $1.17 \pm 0.41$ & 7 & BLCT \\
\hline & Brubru & Nilaus afer & 5 & 0.16 & $1.20 \pm 0.45$ & 6 & BB \\
\hline & Emerald-spotted Wood Dove & Turtur chalcospilos & 5 & 0.16 & $1.00 \pm 0.00$ & 5 & ESWD \\
\hline & White-browed Scrub Robin & Cercotrichas leucophrys & 5 & 0.16 & $1.00 \pm 0.00$ & 5 & WBSR \\
\hline & Greater Blue-eared Starling & Lamprotornis chalybaeus & 5 & 0.16 & $3.20 \pm 2.77$ & 16 & GBES \\
\hline & Arrow-marked Babbler & Turdoides jardineii & 4 & 0.13 & $5.75 \pm 0.96$ & 23 & AMB \\
\hline & Dark-capped Bulbul & Pycnonotus tricolor & 4 & 0.13 & $1.5 \pm 0.58$ & 6 & DCB \\
\hline & Yellow-fronted Canary & Crithagra mozambica & 4 & 0.13 & $2.75 \pm 2.22$ & 11 & YFC \\
\hline & Red-billed Firefinch & Lagonosticta senegala & 4 & 0.13 & $1.5 \pm 0.58$ & 6 & RBF \\
\hline & Tawny-flanked Prinia & Prinia subflava & 4 & 0.13 & $1.75 \pm 0.50$ & 7 & TFP \\
\hline & Southern Grey-headed Sparrow & Passer diffusus & 4 & 0.13 & $1.75 \pm 0.500$ & 7 & SGHS \\
\hline & Blue Waxbill & Uraeginthus angolensis & 4 & 0.13 & $4.25 \pm 0.96$ & 17 & BW \\
\hline & Southern Masked Weaver & Ploceus velatus & 4 & 0.13 & $2.50 \pm 1.29$ & 10 & SMW \\
\hline & Green Wood Hoopoe & Phoeniculus purpureus & 4 & 0.13 & $6.75 \pm 1.71$ & 27 & GW \\
\hline
\end{tabular}




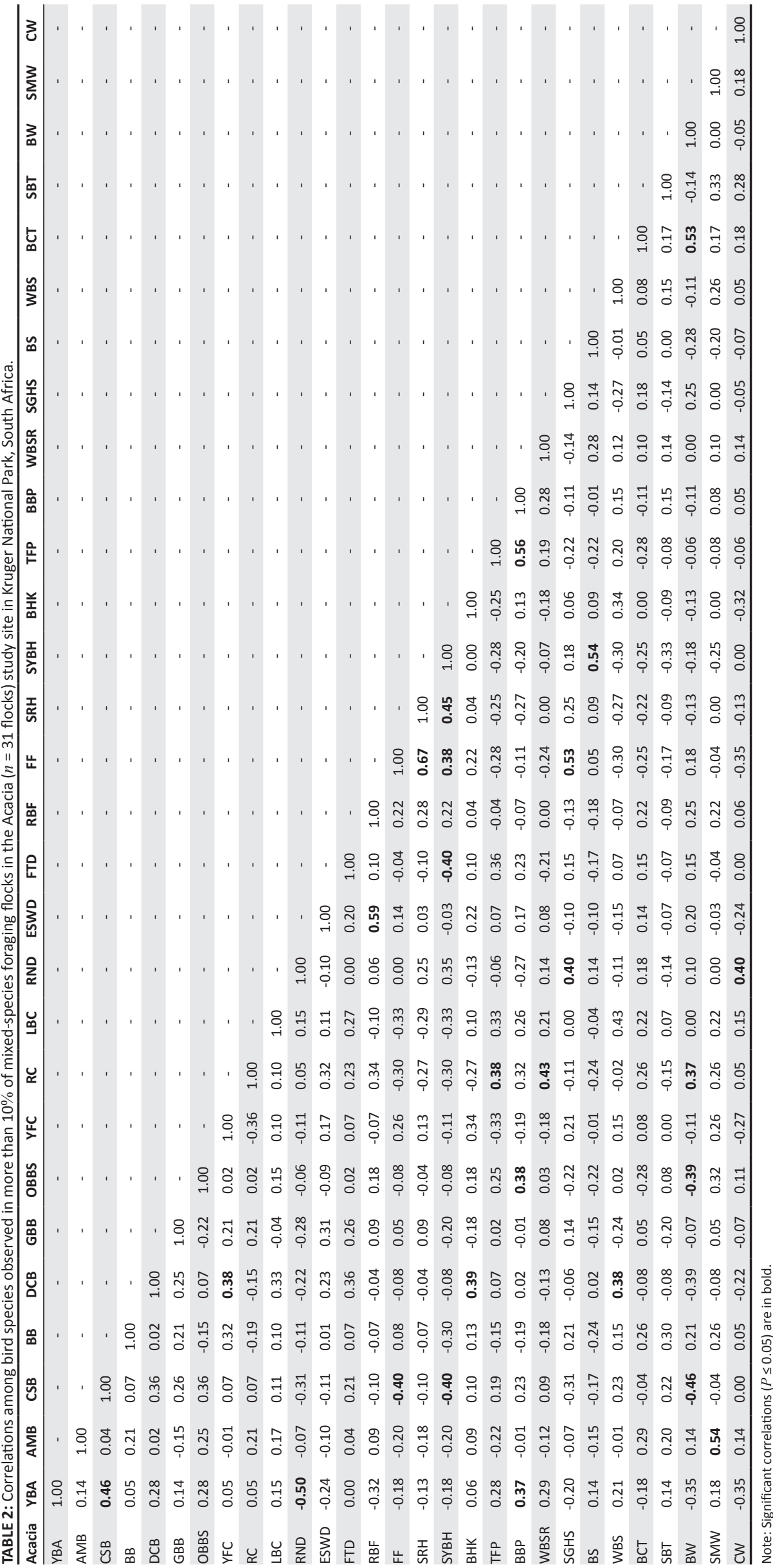




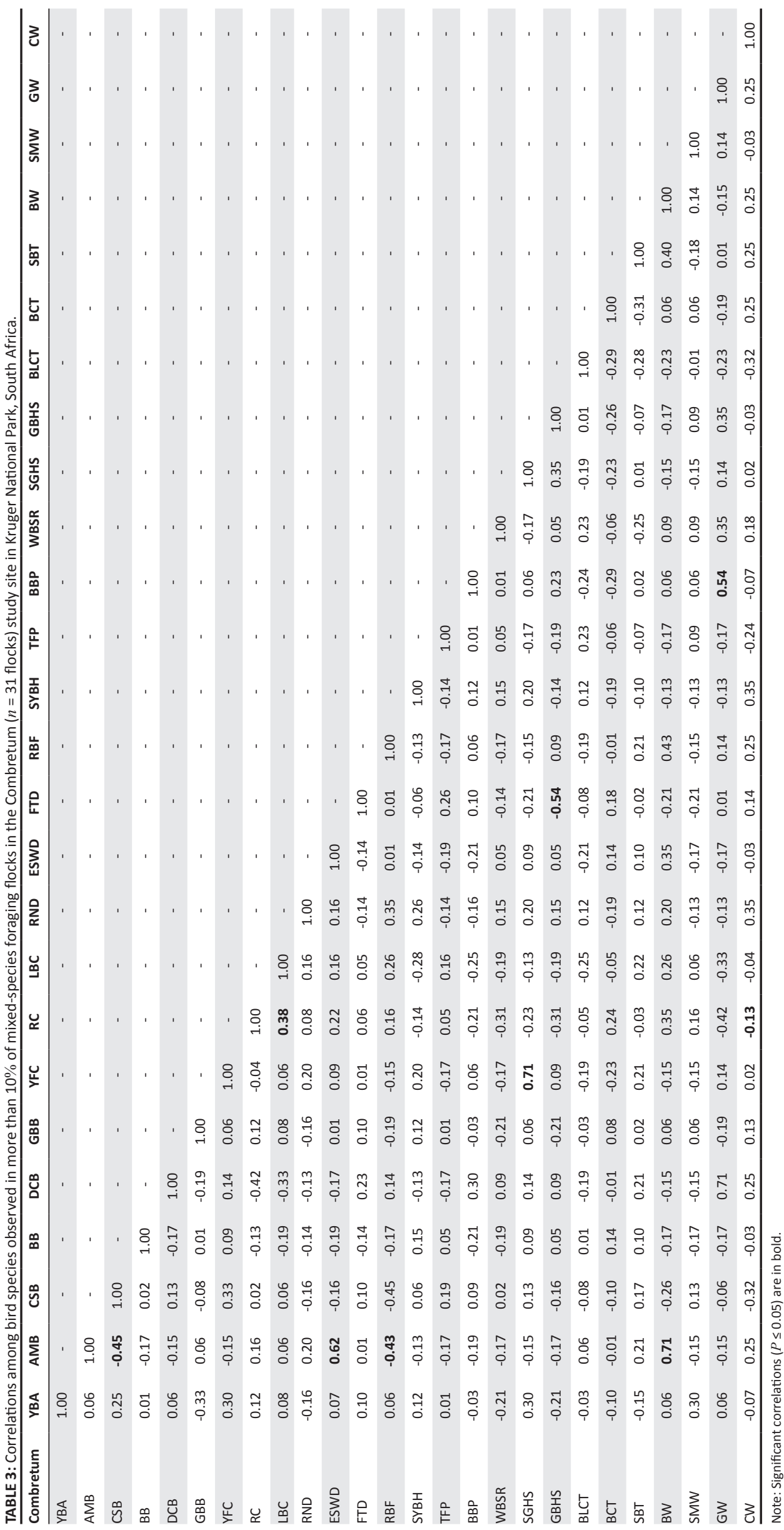


(Croxall 1976; Greig-Smith 1978; Swynnerton 1915; Winterbottom 1943; Zou et al. 2011). In the MSFFs recorded in Nyslvley Nature Reserve, South Africa drongos however occurred in up to $92 \%$ of MSFFs (Thompson \& Ferguson 2007). Drongos have been recorded as a nucleus species of MSFFs in various studies (Cordeiro et al. 2015; Goodale \& Kotagama 2006; Nefdt 1989), and because of their prevalence in MSFFs in this study, drongos are therefore a very likely nucleus species in MSFF of the southern KNP. Other studies have however found that despite drongos occurring in MSFF they do not always take on the role of a nucleus species within a MSFF (Greig-Smith 1978). Of the other frequently encountered species, the Chinspot Batis and Southern Black Tit are notable because both batises (Batis spp.) and tits (Parus spp.) are frequent participants of MSFFs in savannas and forests elsewhere in Africa (Greig-Smith 1978; Nefdt 1989; Thomson \& Ferguson 2007; Winterbottom 1943). In both Acacia and Combretum there was a clear tendency of certain species to be present in the majority of MSFFs. The Chinspot Batis, Southern Black Tit, and Fork-tailed Drongo are frequent participants in both habitat types. The regular occurrence of pairs of Fiscal Flycatchers in MSFFs in the Acacia habitat is noteworthy as this species is an uncommon winter visitor to the KNP (Newman 1991) and this vegetation type probably represents a favoured habitat for these flycatchers when they occur temporarily in this region. The season during which this study was conducted excluded all summer migrants and a similar investigation in the wet season may therefore reveal a different MSFF composition.

The non-random patterns of positive associations among observed MSFFs in this study support findings by King and Rappole (2001) that members of some species tend to associate with other species. King and Rappole (2001) suggested that the reasons for these positive associations between species in MSFFs was to facilitate more efficient foraging by flushing prey from the vegetation through which they move. The reasons for the positive association between MSFF members in this study are likely to be similar, but need further investigation to verify this.

\section{Conclusion}

This study is the first of its kind to be undertaken in the KNP and forms the baseline for ongoing work investigating the composition of MSFFs occurring in the broader landscapes of this region. The analysis of MSFFs could form a valuable component of the biodiversity monitoring currently being undertaken in the KNP, and any future change in the composition and behaviour of MSFFs may be an early indicator of threats to the biodiversity of this region.

\section{Acknowledgements}

We would like to thank South African National Parks and in particular Dr C.C. Grant for her assistance and specialist advice during the course of this project.

\section{Competing interests}

The authors declare that they have no financial or personal relationships which may have inappropriately influenced them in writing this article.

\section{Authors' contributions}

G.H. was responsible for project design, data collection, and initial data analysis. K.S. was the project supervisor, statistically analysed data for final manuscript, and critically reviewed the final article.

\section{References}

Cordeiro, N.J, Borghesio, L., Joho, M.P., Monoski, T.J., Mkongewa, V.J. \& Dampf, C.J., 2015, 'Forest fragmentation in an African biodiversity hotspot impacts mixedspecies bird flocks', Biological Conservation 188, 61-71.

Croxall, J.P., 1976, 'The composition and behaviour of some mixed-species bird flocks in Sarawak', Ibis 118(3), 333-346.

Gertenbach, W.P.D., 1983, 'Landscapes of the Kruger National Park', Koedoe 26, 9-121.

Goodale, E. \& Beauchamp, G., 2010, 'The relationships between leadership and gregariousness in mixed-species bird flocks', Journal of Avian Biology 41, 99-103.

Goodale, E. \& Kotagama, S.W., 2006, 'Vocal mimicry by a passerine bird attracts other species involved in mixed-species flocks', Animal Behaviour 72, 471-477.

Greig-Smith, P.W., 1978, 'The formation, structure and function of mixed-species insectivorous bird flocks in west African savanna woodland', Ibis 120(3), 284-297.

Harrison, N.M. \& Whitehouse, M.J, 2011, 'Mixed-species flocks: An example of niche construction?', Animal Behaviour 81, 675-682.

Hockey, P.A.R., Dean, W.R.J. \& Ryan, P.G. (eds.), 2005, Robert's birds of southern Africa, 7 th edn., The Trustees of the John Voelcker Bird Book Fund, Cape Town.

Hutto, R.L., 1994, 'The composition and social organization of mixed-species flocks in a tropical deciduous forest in western Mexico', Condor 96, 105-118.

Kemp, A.C., Dean, W.J.R., Whyle, I.J., Milton, S.J. \& Benson, P.C., 2003, 'Birds: Responders and contributions to ecological heterogeneity', in J. du Toit, K.H. Rogers \& H.C. Biggs (eds.), The Kruger experience-Ecology and management of savanna heterogeneity, pp. 276-291, Island Press, Washington, DC.

King, D.I. \& Rappole, J.H., 2001, 'Mixed-species bird flocks in dipterocarp forest of north-central Burma (Myanmar)', Ibis 143(4), 380-390.

Morse, D.H., 1970, 'Ecological aspects of some mixed species foraging flocks of birds', Ecological Monographs 40(1), 119-168.

Morse, D.H., 1978, 'Structure and foraging patterns of tits and associated species in English woodland during the winter', Ibis 120(3), 298-312.

Nefdt, R.J.C., 1989, 'A study of some bird parties in Zambia', Ostrich 14, 27-32.

Newman, K., 1991, Birds of the Kruger National Park, rev. edn., Southern Book Publishers, Halfway House.

Skwono, A.L. \& Bond, W.J., 2003, 'Bird community composition in an actively managed savanna reserve, importance of vegetation structure and vegetation composition', Biodiversity and Conservation 12, 2279-2294.

Swynnerton, C.F.M., 1915, 'Mixed bird parties', Ibis 57(2), 346-354.

Thomson, R.L. \& Ferguson, J.W.H., 2007, 'Composition and foraging behaviour of mixed species flocks in two adjacent woodland habitats: A special and temporal perspective', Ostrich 78(1), 65-73.

Venter, F.J., 1990, 'A classification of land for management planning in the Kruger National Park', PhD thesis, University of South Africa, Pretoria.

Venter, F.J., Scholes, R.J. \& Eckhardt, H.C., 2003, 'The abiotic template and its associated vegetation pattern', in J. du Toit, K.H. Rogers \& H.C. Biggs (eds.), The Kruger experience - Ecology and management of savanna heterogeneity, pp. 83-129, Island Press, Washington, DC

Winterbottom, J.M., 1943, 'On woodland bird parties in Northern Rhodesia', Ibis 85(4), 437-442.

Zou, F., Chen, G., Yang, Q. \& Fellows, J.R., 2011, 'Composition of mixed-species flocks and shifts in foraging location of flocking species on Hainan Island, China', Ibis 153(2), 269-278. 